\title{
Harry Aveling and India: A Conversation
}

\author{
Vanashree \\ Professor Emerita, Department of English, Banaras Hindu University, PO box 221005, Varanasi, India
}
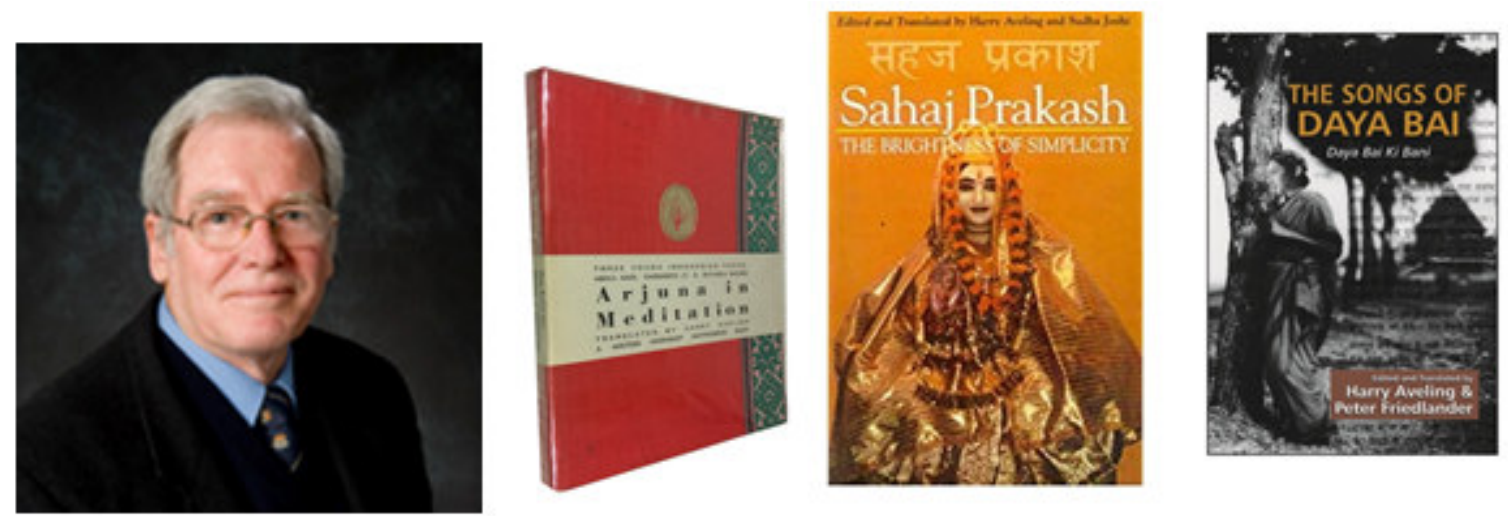

DOI: $10.7176 / \mathrm{JPCR} / 45-04$

Publication date:October $31^{\text {st }} 2019$

\section{Abstract}

During my tenure at Monash University, Australia, as the Indian Council of Cultural Relations (ICCR) chair in Indian Studies, I had the opportunity to get to know the faculty in Monash University and it was indeed gratifying to note that in the western countries there is not just fascination with India but also a genuine quest to know India. Professor Aveling has been looking almost zealously in esoteric books, far corners, and inner reaches for an explanation of himself and in this journey his engagement with translation has had a significant role. It is his profound interest in Indian classical texts and the translation of Bhakti poetry that lifted the veil. I am giving here an account of my conversation with Professor Aveling on 12 May 2017.

\section{What sparked your interest in Indian culture?}

I was born in 1942 and raised in Sydney, Australia. I read Indonesian and Malayan Studiesat the University of Sydney, received my doctorate in Malay Studies from the National University of Singapore, and have taught courses in Southeast Asian Literature in Australia, Malaysia, Indonesia and the United States of America for over five decades. During that time, Indian culture - particularly Indian religion and literature - formed an important part of my life.

\section{Beginnings}

Do you find resonances of classic Indian texts in Indonesian literature?

Indian culture is, of course, a significant component of Indonesian culture. During my undergraduate studies I came to know how strongly the culture of South Asia is woven into that of Southeast Asia. As the great sociologist Clifford Geertz has written with reference to the Indianised worldview of the priyayi gentry: "The refined politesse, the high art, and the intuitive mysticism all remain characteristic of Java's social elite; and, although somewhat attenuated and adjusted to changed conditions, the priyayi life style remains the model not only for the elite but in many ways for the entire society."

I read the stories of the Mahabharata and the Ramayana, which are the foundation of the wayang shadowpuppet theatre and much classical Malay and Indonesian literature. I read the Hikayat Seri Rama, the Chronicle of Rama, which is one of the oldest surviving texts in Malay and is derived from the Bhattikavyam, rather than Valmiki'sRamayana, which inspired the Old Javanese KakawinRamayana,which was composed some time before $930 \mathrm{CE}^{2}$

Most importantly, I discovered Heinrich Zimmer's book the Philosophies of India (RKP, London1953), which I used to take away to the solitude of the highlands south of Sydney during the university vacations to read and meditate upon. The Philosophies of India is an ideal book for a young man to come in contact with. It is not overly technical in its presentation of Indian philosophy and it includes some immediately useful stories. The first chapter contains the parable of the tiger cub raised among goats, who had to be encouraged to find his own real nature. Chapter 2 contains the story of the young Brahmin who had been taught by Sankaracarya that

\footnotetext{
${ }^{1}$ Religion of Java, Free Press, Glencoe 1960, p. 6.

2 See Stuart Robson (ed. and trans.): The Old Javanese Rāmāyana; A new English Translation with an Introduction and Notes. Javanese Studies 2. Tokyo: Research Institute for Languages and Cultures of Asia and Africa, Tokyo University of Foreign Studies 2015. (812 pp.)
} 
everything was illusion, but also that he should get out of the way of marauding elephants, because although the elephant is ultimately unreal (being maya) and so is he (also being maya), both he and the elephant operate in the same worldly dimension and wisdom should be tempered by practical sense. The Philosophies of India also sets out a model of the fully developed ascetic: learned, self-controlled, living a simple lifestyle in a natural environment, which has continued to ground and challenge me to this day.

\section{Publishing with Writers Workshop}

How did you come to decide to publish your works in India?

In 1972, I moved to Penang to teach at the Science University of Malaysia. Here I was regularly immersed in Indian society, especially Tamil culture. I had already begun translating Indonesian literature into English, including an anthology of Contemporary IndonesianPoetry (University of Queensland Press 1975) and a collection of short stories, A Heap of Ashes (also UQP 1975), by the Indonesian social realist author, PramoedyaAnantaToer, then a political prisoner.

I then began publishing my translations in India through the P. Lal's Writers Workshop in Calcutta. The books were exquisitely presented: "hand-set in Universe typeface \& printed on an Indian-made hand-operated machine by P.K. Aditya at the Lake Gardens Press, Calcutta 45, on map-litho paper made in India. Layout \& lettering by P. Lal. Hand-bound by TulamiahMohiddeen with cotton handloom sari-cloth woven in India."

Which of your books did Professor P. Lal publish?

Professor Lal published four of my books: Arjuna in Meditation: Three Young Indonesian Poets (1976), The Mastadon andthe Condors by W.S. Rendra (1981), The Interior Landscape of the Heart (1981) and Koong, The Story of a Pigeon byIwanSimatupang (1986). The Interior Landscape of the Heart was an anthology of nine Indian poets living in Malaysia and Singapore, co-edited with Dr. Dhandayudham of the University of Malaya and initially translated by my former students and colleagues. It was my first experience of co-translation -- a group of translators working together--one of whom knew the source language well, the other who was adept in the target language, English. There are no doubt problems with this method but it allows for the production of translations that would not otherwise be possible. ${ }^{3} \mathrm{I}$ have since used it often in bringing lesser-known Indian texts to the attention of the English reading public.

\section{Yoga, Discipleship, Sannyasa}

As far as the Yogasutras and the Gitaare concerned, did you receive any kind of expertguidance? It is to these traditions that you are drawn as a serious seeker of enlightenment. How did you approach the translations of these Indian texts?

After Penang, I moved to Perth, Western Australia, where I was Dean of the School of Humanities at Murdoch University between 1977 and 1979. Here I met Swami Venkatesananda, a disciple of the late Swami Sivananda of Rishikesh. Venkatesananda was a man of immense charm and great learning. He had prepared editions of the Bhagavad Gita, the Yoga Sutras, the Vasistha Ramayana, and a number of other spiritual texts. By this time I was an established translator and academic. He taught me to search for the hidden nuances of texts. His "new interpretive translation" of the Yoga Sutras, for example, begins with the first verse, "athayoga'nusasanam", and renders it: "Now, when a sincere seeker approaches an enlightened teacher, with the right attitude of discipleship (viz. free of preconceived notions and prejudices, and full of intelligent faith and receptivity) and with the right spirit of enquiry, at the right time and the right place, communication of yoga takes place." Of course, that is exactly what the verse is saying.

How did you introduce the esoteric philosophical debates of the Vedic texts to your students in the university?

I taught introductory courses on Hinduism and Buddhism. The Gita held an important place in the former course: I encouraged my students to read it slowly and carefully, not just as an academic exercise but as a way of coming to terms with one of the great religious texts of all mankind. The subtleties of the Yoga Vasistha were beyond undergraduate students, as Swamiji presented the paradoxes of Vedanta, puranas and popular legends, but I was honoured that Venkatesananda spoke to my classes on several occasions, making the students well aware of the complexity and simple grace of the tradition he represented.

Were Swamiji's teachings limited to your academic interests in classical Indian literature, or did they have a deeper significance in your own spiritual life as well?

He showed me how the true sannyasin lives. This was important because I became a disciple of the contemporary enlightened mystic, Bhagwan Shree Rajneesh on 6 September 1977, Krishna Janmashtami (under the name of AnandHaridas). Osho, as he is now known, recognized that sannyasa was a life style beyond conventional social rules and he gave his disciples great freedom in deciding how their lives could best be lived

\footnotetext{
${ }^{3}$ On co-translation, see my paper "On translating from languages one does not know: Faking the Pumpkin" in (ed.) Francesca Benocci and Marco Sonzogni: Translation,Transnation alism, World Literature (Joker, Novi Ligura 2015), pp. 45-63.
} 
out. This could be difficult for those who had no role models to follow. I had both Venkatesa and the yoga master, Swami Satyananda of Munger, Bihar, another disciple of Sivananda's, to learn from. I loved the subtlety of Osho's mind, the spiritual richness of his discourses, and the positive playfulness of his affirmation of the world.

\section{Osho}

\section{Was Osho a significant influence in your life and works?}

My association with Osho led to no less than five books and two articles for authoritative encyclopedias (The Encyclopedia of Hinduism and the Encyclopedia of Western Australian History). I wrote a book called The Laughing Swamis: Australian SannyasinDisciples of Swami SatyanandaSaraswati and Osho Rajneesh (MotilalBanarsidass, New Delhi 1994), drawing on my experience and that of others in both of these traditions, and edited a collection of Western Perceptions of Osho Rajneesh and His disciples (MLB 1999).

Together with Mrs Sudha Joshi, Head of the Hindi Department at La Trobe University in Melbourne, I cotranslated Osho's discourses on DayaBai, The Last Morning Star (2000, now published by Jaico, without our names as translators!). Mrs Joshi and I then moved on from the discourses to the poetry itself. First we cotranslated the devotional poetry of Daya Bai's sister disciple, Sahajo Bai, Sahaj Prakash, The Brightness of Simplicity (Motilal 2001). After Mrs Joshi's retirement, I co-translated Daya Bai's own Songs with Peter Friedlander (Prestige Books, New Delhi 2005) and a small selection of their Master, Charandas's work, Bhaktipadarth (Prestige Books 2014).

The names of DayaBai or Charandas hardly appear in the mainstream histories of bhakti literature. What do you think makes their contribution noteworthy?

The Charandassampradaya comes at the end of the bhakti tradition and is, in fact, often overlooked. Charandas was born in 1703 and passed away in 1782. Sahajo was perhaps his cousin and was born in 1725 . We have no dates for Daya; it is sometimes suggested that she was Sahajo's sister but there is no real evidence for this. Charandas was a prolific author and a devotee of Lord Krishna, whom he claimed to have met several times in his life. Sahajo and Daya primarily wrote of devotion to the guru. One of Sahajo's most extraordinary poems begins: "I might leave Rama, I could never leave my guru/ In my eyes, Hari is not the equal of my Master./ Hari brought me into this world,/ The guru freed me from the cycle of birth and death ..."(As Osho has said: this is a subtle quarrel between two lovers. "Just think", he asks, "how can she put him lower? Can one who cannot put her master lower than God put God himself lower than the master? Impossible!"”4)

In their poetry, the two women used the figure of Krishna, together with Rama and Brahma, as symbols of the abstract Divine, as Charandas himself did. Unlike Meera, however, there is no hint of eroticism in their work. Neither Sahajo nor Daya identified with Radha or the gopis. Instead, they claimed a lowly place within the community of sants. Sahajo described herself as "a woman without any greatness", a servant whose place was outside the master's door, ready to answer his call at any moment. She was confident that: "The bonds of love protect me/ they will never break." Daya too insisted: "I am the lowest of all the sadhus. There is no wisdom in me./ Hari's merciful people pitied me and made me one of their own."

\section{Scholarly Engagement with the Epics}

Getting back to our earlier discussion on the classical Indian texts, how would you address them from the Southeast-Asian perspective?

I should mention my scholarly essays on the great epics from a Southeast Asian perspective.

"Sita puts out the fire" is a study of Sita's testing by fire as a proof of her chastity and of her loyalty to her husband, in Indonesian, Malay and Thai literatures. There are many subtle deviations from the Indian texts in these localized versions. In the Hikayat Seri Rama, composed some time before $1633 \mathrm{CE}$ and already bearing traces of Muslim revision, Rama himself plunges into the pyre to rescue Sita, insisting that he has never really doubted her faithfulness to him. In the Thai Ramakien, perhaps 1785, Rama is not presented as a god, but as a fallible man, who blames his wife unreasonably, because he is ruled by jealousy and romantic love.

Both of these classical texts present a patriarchal view of Sita, approving of Sita's subordination to Rama's demands. In modern Southeast Asian literatures, we also have what might be called an "anti-Sita" characterization of the heroine as well (anti the traditional image of Sita), in which she rejects submission to her husband and asserts her own independent individuality. Leila Chudori's short story, "The Purification of Sita" (Air SuciSita1988), for example, presents Rama as a pompous, self-righteous, patriarchal hypocrite. Dorothea Rosa Herliany's poem, "Sita's Elegy" (ElegiSita 2005), condemns Rama as "a coward", "a weak man" and a "liar", as Sita actively seeks a romantic interlude with Ravana. 'In her short stories, the Thai author Sri Daoruang

\footnotetext{
${ }^{4}$ Osho: Showering without Clouds, Rebel Publishing House, Pune 1998, pp. 41-42.)

${ }^{5}$ Bridging the Past and the Present: A Festschrift Honouring Muhammad Haji Salleh, ed. by Ding Choo Ming and Zalina Abdul Aziz, DewanBahasadanPustaka, Kuala Lumpur 2015, pp. 86-114.

${ }^{6}$ Such anti-Sita views can also be found in Paula Richman's Ramayana Stories in Modern South India: An Anthology, University of
} 
places "Sida", "Thotsakan" - Ravana, Sida's husband! And their child, Hanuman within the setting of modern Bangkok, and leaves them to grapple with contemporary problems of debt, disagreement and potential dishonesty in their marriage.

"Abimanyugugur: The death of Abimanyu in Classical and Modern Indonesian and Malay Literature" was originally presented to a conference held in Singapore and is still "in press". In this paper, I show how the original Sanskrit story, and its ideology of ksatria dharma, is modified as it is framed by other cultures. The Old Javanese KakawinBharatayuddha, composed between 1157 and 1159, presents Abimanyu's death as both a poetic and an erotic act, an example of the "tantricism" of the battlefield, uniting sexuality, poetry and death in a beautiful and profoundly emotional ritual. The Malay HikayatPandawaLima (Chronicle of the Five Pandawa) emphasizes the mediaeval Malay courtly virtue of dying with "a good name" as the ultimate justification for Abimanyu's death. The modern Indonesian retelling, "Nostalgia" (1969) by Danarto, is written from a profoundly pantheistic (priyayi) perspective. Abimanyu is cursed to be famous for all eternity ("it would be best to vanish from history entirely," Krishna tells him) but his death is a necessary step in his returning to his primal nature ("A man receives philosophy, statecraft and art automatically once he achieves true knowledge of the essence of Creation and the being of God"). As he dies, he chants in a manner drawn from the Bhagavad Gita itself, beginning: "I am Kuruksetra, the field of battle. I am the Pandawa and the Kurawa. I am the strategy, the army, the heroes and the cowards ..."

\section{On Moving the Indian Traditions across Cultures}

What is your view of the cultural translations of Indian texts - I mean the long journeys made by the Indian texts across cultures?

Scholarship is a complex affair. The scholar is not only dealing with words, and words never carry exactly the same meaning between different languages, but also with different cultures, different ideas about how people should behave and how the world works, and different expectations about what counts as literature and the ways in which good literature should be written.

As a person, scholar and translator, I am both an "insider" and "outsider" to India, someone who moves between these different cultures, in order to analyze, describe and translate them, so that other people, inside and out, can understand them better.

How would you assess your contribution towards Indian and Southeast Asian literature?

Like the four-headed Brahma, I have face in many directions, towards India, towards Indonesia and Malaysia, towards Australia. My work on Southeast Asia and my life have been shaped and influenced by Indian literature and religion. I have shared Indonesia and Malaysia with India. Perhaps most originally, I have drawn the attention of English speaking students of the bhakti tradition to the often neglected Charandas sampradaya, and I have also attempted to show how traditional ideas of renunciation have been reworked by contemporary teachers, including my own teacher Osho.

Acknowledgements: I heartily thank Professor Harry Aveling, Professor Felix Nobis, ICCR, New Delhi, the Indian Studies programme at Monash University, and Banaras Hindu University.

California Press, Berkeley 2008. 